\title{
NITROGEN LOSS IN Brachiaria decumbens AFTER APPLICATION OF GLYPHOSATE OR GLUFOSINATE-AMMONIUM
}

\author{
Virginia Damin ${ }^{1}$; Henrique Coutinho Junqueira Francoํ; Milton Ferreira Moraes ${ }^{3}$; Ademir \\ Franco $^{3}$; Paulo Cesar Ocheuze Trivelin²* \\ ${ }^{1}$ USP/ESALQ - Programa de Pós-Graduação em Solos e Nutrição de Plantas, C.P. 09 - 13418-900 - Piracicaba, \\ $S P$ - Brasil. \\ ${ }^{2}$ USP/CENA - Lab. de Isótopos Estáveis, C.P. 970 - 13400-970 - Piracicaba, SP - Brasil. \\ ${ }^{3}$ USP/CENA - Programa de Pós-Graduação em Energia Nuclear na Agricultura e no Ambiente, C.P. 970 - \\ 13400-970 - Piracicaba, SP - Brasil. \\ *Corresponding author: <pcotrive@cena.usp.br>
}

\begin{abstract}
Nitrogen losses from the soil-plant system may be influenced by herbicide applications. In order to evaluate $\mathrm{N}$ loss in brachiaria (Brachiaria decumbens) after application of the herbicides glyphosate and glufosinate-ammonium, an experiment was carried out in a greenhouse as a completely randomized design, with three treatments and six replicates. Treatments were as follows: i) desiccation of brachiaria-plants with glyphosate; ii) desiccation of brachiaria-plants with glufosinate-ammonium; and iii) control, without herbicide application. The plants were cultivated in $4 \mathrm{~kg}$ pots of sandy soil and fertilized with ammonium sulfate- ${ }^{15} \mathrm{~N}$, $\left(200 \mathrm{mg} \mathrm{kg}^{-1}\right)$ in order to quantify the allocation of the fertilizer$\mathrm{N}$ and its recovery in the soil-plant system. Plants treated with the herbicides had less $\mathrm{N}$ accumulation and less recovery of the fertilizer- $\mathrm{N}\left({ }^{15} \mathrm{~N}\right)$ relative to the control. In the soil, the greatest recovery of ${ }^{15} \mathrm{~N}$-fertilizer occurred for treatments where $\mathrm{N}$ was applied, possibly due to the occurrence of other $\mathrm{N}$ compound losses to the soil, like root exudation and root death. The total recovery of ${ }^{15} \mathrm{~N}$-fertilizer in the soil-plant system was higher in the control than in the treated plants showing the direct action of the herbicides on nitrogen loss, and especially by the above-ground part of the brachiaria plants. Key words: ${ }^{15} \mathrm{~N}$, ammonium exchange, Gramineae, herbicides
\end{abstract}

\section{PERDAS DE NITROGÊNIO POR Brachiaria decumbens APÓS A APLICAÇÃO DE GLIFOSATO OU GLUFOSINATO DE AMÔNIO}

RESUMO: As perdas de nitrogênio no sistema solo-planta podem ser influenciadas pela aplicação de herbicidas. Com o objetivo de avaliar a perda de $\mathrm{N}$ do capim-Brachiaria (Brachiaria decumbens) após a aplicação dos herbicidas glifosato e glufosinato de amônio, foi realizado um experimento em casade-vegetação em delineamento inteiramente aleatorizado (DIA), com três tratamentos e seis repetições. Os tratamentos foram os seguintes: i) dessecação de plantas de braquiária com o herbicida glifosato; ii) dessecação de plantas de braquiária com herbicida glufosinato de amônio e iii) testemunha, sem aplicação de herbicida. As plantas foram cultivadas em vasos com $4 \mathrm{~kg}$ de solo arenoso e foram fertilizadas com sulfato de amônio $\left({ }^{15} \mathrm{~N}\right)$, na dose de $200 \mathrm{mg} \mathrm{kg}^{-1}$, com o intuito de quantificar a alocação de $\mathrm{N}$-fertilizante $\left({ }^{15} \mathrm{~N}\right)$ e sua recuperação no sistema solo-planta. As plantas tratadas com os herbicidas apresentaram menor acúmulo de $\mathrm{N}$ e menor recuperação do $\mathrm{N}$-fertilizante $\left({ }^{15} \mathrm{~N}\right)$ em relação à testemunha. No solo a maior recuperação do ${ }^{15} \mathrm{~N}$-fertilizante ocorreu nos tratamentos em que foram aplicados os herbicidas, possivelmente, devido à ocorrência de perda de compostos nitrogenados para o solo por exsudação radicular e morte de raízes. A recuperação total do ${ }^{15} \mathrm{~N}$-fertilizante no sistema solo-planta foi maior na testemunha que nos tratamentos, evidenciando-se a ação direta dos herbicidas nas perdas de nitrogênio, especialmente, pela parte aérea do capim-Brachiaria.

Palavras-chave: ${ }^{15} \mathrm{~N}$, perdas de nitrogênio, braquiária, herbicidas

\section{INTRODUCTION}

Nitrogen fertilization is one of the recommended practices to obtain good productivities in agricultural systems. On the other hand, nitrogen fertil- izers are costly and their inappropriate use may cause environmental problems like the emission of greenhouse effect gases and the contamination of subsurface waters with nitrate (Sherlock et al., 1989). Thus the adoption of management practices that minimize 
nitrogen losses in the system is most required in order to increase nitrogen fertilization effectiveness. Among the most important forms of nitrogen losses from the soil-plant system are the removal by the crop, ammonia volatilization, gaseous losses of nitrogen forms $\left(\mathrm{NO}_{2}, \mathrm{~N}_{2} \mathrm{O}, \mathrm{NO}\right)$, and elemental nitrogen $\left(\mathrm{N}_{2}\right)$, nitrate leaching out of the reach of the root system, and $\mathrm{N}$ losses by plant foliage.

Nitrogen losses by the above-ground part of plants may contribute to increase ammonium levels in the atmosphere, e.g. $\mathrm{NH}_{3}-\mathrm{N}$ emission values by plants in the order of 5-15 kg ha ${ }^{-1}$ year $^{-1}$ (Sutton et al., 1993). This nitrogen loss pathway could be responsible for $15-20 \%$ of all gaseous emissions of $\mathrm{NH}_{3}$ (Asman et al., 1998). The magnitude of natural nitrogen losses by the aerial part of crops may vary according to the grown species, plant developmental stage, nitrogen availability in the soil, stomatal conductance, leaf temperature, plant stress due to diseases, water deficit, $\mathrm{NH}_{3}$ level in the atmosphere, ammonium concentration in the plant, and the activity of the glutamine synthetase enzyme (Schjoerring et al., 1998; Parton et al., 1988). Some herbicides may also affect one or more of these factors and, as a result, may increase $\mathrm{N}$ losses by the above-ground part of plants.

Therefore, evaluating the influence of herbicides on nitrogen losses becomes especially relevant to allow the preparation of fertilizer- $\mathrm{N}$ management strategies that will provide better agronomic nitrogen fertilization effectiveness, and consequently less environmental impact. The objective of this study was to evaluate nitrogen losses by Brachiaria decumbens after application of the herbicides glyphosate and glufosinate-ammonium.

\section{MATERIAL AND METHODS}

The experiment was developed in Piracicaba, State of São Paulo, Brazil, from July to November, 2005, under greenhouse conditions, using a completely randomized design (CRD), with three treatments and six replicates. Treatments consisted of: (i) Glyphosate - brachiaria desiccation with the herbicide glyphosate; (ii) Glufosinate - brachiaria desiccation with the herbicide glufosinate-ammonium; and (iii) control brachiaria without herbicide application.

Pots were filled with $4 \mathrm{~kg}$ air-dried sandy soil (ADS) from a Typic Quartzipsamment, with the following chemical characterization of the $0-20 \mathrm{~cm}$ layer: $\mathrm{pH}\left(\mathrm{CaCl}_{2}\right)$ 4.1; $4 \mathrm{~g} \mathrm{~kg}^{-1}$ organic matter (O. M.); $1 \mathrm{mg}$ $\mathrm{dm}^{-3} \mathrm{P}$ (extracted with resin), $7 \mathrm{mg} \mathrm{kg}^{-1} \mathrm{~S}_{-} \mathrm{SO}_{4}$; $\mathrm{K}, \mathrm{Ca}$, $\mathrm{Mg}, \mathrm{H}+\mathrm{Al}, \mathrm{Al}$, Sum of bases and CEC: $0.3 ; 5 ; 2 ; 25$; 8; 7; and $32 \mathrm{mmol}_{\mathrm{c}} \mathrm{dm}^{-3}$ respectively. Soil acidity and fertility were corrected before planting the brachiaria grass. The amount of lime required for acidity correction was determined according to Penatti \& Forti (1994), using dolomitic lime (TNP $=91 \%$ ), at the proportion of $1.5 \mathrm{~g} \mathrm{~kg}^{-1}$ soil. The corrective material was applied together with $200 \mathrm{mg} \mathrm{kg}^{-1} \mathrm{P}$ in the form of triple superphosphate, and homogenized in the entire soil volume. Later, each plot received the application of $100 \mathrm{~mL}$ of a solution containing $150 \mathrm{mg} \mathrm{kg}^{-1} \mathrm{~K}$ (potassium chloride p.a.), $4 \mathrm{mg} \mathrm{kg}^{-1} \mathrm{Zn}$ (zinc sulfate p.a.), $4 \mathrm{mg} \mathrm{kg}^{-1} \mathrm{~B}$ (boric acid p.a.) and $12 \mathrm{mg} \mathrm{kg}^{-1} \mathrm{Cu}$ (copper sulfate p.a.). After the acidity and fertility corrections, the soil was moistened with $500 \mathrm{~mL}$ distilled water ( $80 \%$ of the soil's maximum water retention capacity) and incubated for a 15-day period.

At the end of the incubation period, on 07/29/ 2005, 100 brachiaria seeds (Brachiaria decumbens) were manually sown per plot. On 09/02/2005 the aerial part of the forage was cut for uniformity at an approximate height of $10 \mathrm{~cm}$ above the ground. The nitrogen fertilizer (ammonium sulfate) was applied on the same date at a rate of $200 \mathrm{mg} \mathrm{kg}^{-1} \mathrm{~N}$, labeled with 3.03 atoms $\%$ of ${ }^{15} \mathrm{~N}$. The $\mathrm{N}$ was applied in the solution form (50 mL per pot) and then $50 \mathrm{~mL}$ distilled water were added to each pot. During the entire experimental period, the soil in the pots was irrigated daily and the soil maximum water retention capacity was kept near $60 \%$.

The plants in the control treatment were harvested on 10/24/2005 (onset of flowering). The application of herbicides to the remaining treatments was performed on the same date using the herbicides gliphosate, at a rate of $4 \mathrm{~L} \mathrm{ha}^{-1}, 480 \mathrm{~g} \mathrm{~L}^{-1}$ a.i., and glufosinate-ammonium, at a rate of $2.0 \mathrm{~L} \mathrm{ha}^{-1}$, $200 \mathrm{~g} \mathrm{~L}^{-1}$ a.i. Directed herbicide applications were performed with a back-pack sprayer equipped with a $1 \mathrm{~m}$ long boom and a flat-fan nozzle at an application swath width of $1 \mathrm{~m}$. The plants in treatments with glyphosate or glufosinate were harvested 10 days after the herbicides were applied (11/03/2005).

The brachiaria plants of each plot were separated into above-ground parts and roots. The aboveground parts were cut at ground level and the soil was separated from the roots using a 2-mm mesh sieve. The roots were then washed to remove soil that still remained adhered to them. The above-ground parts and roots of the brachiaria plants were dried in a forced air circulation oven at $65^{\circ} \mathrm{C}$ before weighing. The soil of each plot was weighed to determine total and airdried mass. Soil subsamples were taken for moisture determination.

For total $\mathrm{N}$ and ${ }^{15} \mathrm{~N}$ abundance determinations, the oven-dried above-ground parts and root samples were ground in a Wiley mill, and the soil was passed through a ball mill. After the samples were prepared, 
$\mathrm{N}$-total and ${ }^{15} \mathrm{~N}$ abundance determinations were obtained in a mass spectrometer containing an automatic $\mathrm{N}$ analyzer, model ANCA-SL, 20-20 from PDZ Europe, Crewe, UK, (Barrie \& Prosser, 1996).

The nitrogen recovery NPPF (mg per pot) from the ammonium sulfate fertilizer was calculated by the expression:

$\mathrm{NPPF}=[(\mathrm{a}-\mathrm{c}) /(\mathrm{b}-\mathrm{c})] . \mathrm{N}_{\mathrm{t}}$

where: a $-{ }^{15} \mathrm{~N}$ abundance (atom \%) in the sample plant or soil; $\mathrm{b}-{ }^{15} \mathrm{~N}$ abundance in the ammonium sulfate (3.03 atom $\left.\%{ }^{15} \mathrm{~N}\right)$; c $-{ }^{15} \mathrm{~N}$ natural abundance $(0.367$ atom $\left.\%{ }^{15} \mathrm{~N}\right) ; \mathrm{N}_{\mathrm{t}}$ - total $\mathrm{N}$ content in the sample plant or soil (mg per pot).

The $\mathrm{N}$ percentage recovery $\% \mathrm{R}$ from the ammonium sulfate in the plant and soil was calculated as:

$\% \mathrm{R}=(\mathrm{NPPF} / \mathrm{D}) * 100$

where $\mathrm{D}$ is the rate of applied $\mathrm{N}$ (800 mg per pot)

The results obtained were submitted to analysis of variance and treatment means were compared by the Tukey test ( $p=0.1$ and $p=0.05)$.

\section{RESULTS AND DISCUSSION}

The dry mass yield of the above-ground parts and from the entire brachiaria plants was smaller in the glufosinate treatment (Table 1). This difference could be linked to the rapid action of the herbicide, since plants receiving this herbicide showed earlier se- nescence than those treated with glyphosate. There was no difference between treatments for dry root mass yield, although the control yielded 38\% more dry mass than the glufosinate treatment. The lack of significance (Tukey, $p<0.1$ ) is perhaps related to the $27 \%$ coefficient of variation (Table 1 ). For $\mathrm{N}$ accumulation in the brachiaria plants (Table 2), the control presented the highest mean, demonstrating a total $\mathrm{N}$ reduction in the plants after the application of desiccants, in the order of 36 and $40 \% \mathrm{~N}$, respectively, for glyphosate and glufosinate.

Glufosinate inhibits the action of the enzyme glutamine synthetase, which is responsible for the glutamate synthesis from ammonium and glutamine. This metabolic pathway is considered the most important ammonium assimilation route in organic compounds (Schjoerring et al., 1998). As a consequence, the application of glufosinate-ammonium results in an endogenous $\mathrm{NH}_{4}^{+}$accumulation in the plant (Wild \& Manderscheid, 1984). At high concentrations, $\mathrm{NH}_{4}^{+}$is toxic to plants, and may result in greater $\mathrm{NH}_{3}$ emissions by them via the stomata (Holton-Hortwing \& Bockman, 1994). The glutamine shynthetase inhibition effect on the ammonium concentration was evaluated for barley plant tissues and the observed concentration increased when the activity of the enzyme was inhibited (Mattson et al, 1998). Similar results were found by Lea (1991).

Glyphosate also influences the ammonium concentration in the plant (Christoffoleti et al., 2001;

Table 1 - Dry matter from roots, above-ground parts and entire plant of Brachiaria decumbens.

\begin{tabular}{lccc}
\hline \multirow{2}{*}{ Treatments } & \multicolumn{3}{c}{ Dry matter } \\
\cline { 2 - 4 } & Roots & Above-ground parts & Entire plant \\
\hline Control & $15.0 \mathrm{a}$ & $26.4 \mathrm{a}$ & $41.4 \mathrm{a}$ \\
Glyphosate & $12.3 \mathrm{a}$ & $26.6 \mathrm{a}$ & $40.0 \mathrm{ab}$ \\
Glufosinate & $10.9 \mathrm{a}$ & $21.3 \mathrm{~b}$ & $32.2 \mathrm{~b}$ \\
\hline CV $(\%)$ & 27 & 10 & 14 \\
\hline
\end{tabular}

Means followed by different letters, in columns, differ from each other by Tukey's Test $(p=0.1)$.

Table 2 - Total N in root, above-ground part and entire plant of Brachiaria decumbens.

\begin{tabular}{lccc}
\hline \multirow{2}{*}{ Treatments } & \multicolumn{3}{c}{ Dry matter } \\
\cline { 2 - 4 } & Roots & Above-ground parts* & Entire plant \\
\hline Control & $186.8 \mathrm{a}$ & $336.8 \mathrm{a}$ & $523.6 \mathrm{a}$ \\
Glyphosate & $93.0 \mathrm{~b}$ & $242.8 \mathrm{ab}$ & $335.8 \mathrm{~b}$ \\
Glufosinate & $78.5 \mathrm{~b}$ & $237.8 \mathrm{~b}$ & $316.3 \mathrm{~b}$ \\
\hline CV $(\%)$ & 32 & 27 & 25 \\
\hline
\end{tabular}

Means followed by different letters, in columns, differ from each other by Tukey’s Test $(p=0.05)$. Means followed by different letters, in columns, differ from each other by Tukey's Test $(p=0.1)$ 
Kissmann, 2003), although not directly as verified for glufosinate. The herbicidal action of glyphosate is attributed to the inhibition of the EPSPS enzyme (Enolpyruvylshikimate phosphate synthase), responsible for one of the synthesis steps of the amino acids tryptophan, phenylalanine, and tyrosine. So, as a side effect, glyphosate increases the activity of the enzyme phenylalanine ammonia-lyase, which acts on the breakdown of amino acids phenylalanine and tyrosine, resulting in the formation of phenolic acids and ammonium (Hoagland, 1981).

The intensity and direction at which ammonia exchanges occur between the leaves and the atmosphere also depend on the ammonia compensation point (Farquhar et al., 1980), which may vary with temperature, light intensity, photoperiod, plant nitrogen nutrition, species and cultivar of that particular species, and vegetative stage of the plant (Holtan-Hartwing \& Bockman, 1994; Husted \& Schjoerring, 1996; Mattsson et al., 1997; Mattsson \& Schjoerring, 1996; Schjoerring et al., 1998). Ammonia emission by the leaves will occur for $\mathrm{NH}_{3}$ concentration values in the atmosphere below plant ammonia compensation point; conversely, ammonia absorption will occur for concentrations above that point (Farquhar et al., 1980; Holtan-Hartwing \& Bockman, 1994). Beside that, these losses depend on the balance, in the solution, between the $\mathrm{NH}_{3}$ gaseous form and the $\mathrm{NH}_{4}^{+}$ionic form, which is influenced by temperature and $\mathrm{pH}$ of the medium (Holtan-Hartwing \& Bockman, 1994).

With regard to the recovery of ${ }^{15} \mathrm{~N}$-fertilizer from the entire plant, a similar behavior for $\mathrm{N}$ losses from the isotope can be verified (Table 3 ) in relation to total $\mathrm{N}$ losses (Table 2), since plants treated with the herbicides recovered less ${ }^{15} \mathrm{~N}$-fertilizer, about 37 (glyphosate) and $40 \%$ (glufosinate) in relation to the control, practically the same values observed for total N (Table 2).
The recovery of ${ }^{15} \mathrm{~N}$-fertilizer from the soil was small (Table 3) when compared with other reports. A recovery rate in the order of $20 \%$ of ${ }^{15} \mathrm{~N}$-fertilizer from the soil was observed by Oliveira (2001) after harvesting the above-ground part of brachiaria (Brachiaria brizantha). On the other hand, the recovery of ${ }^{15} \mathrm{~N}$-fertilizer from the soil (Table 3) for the treatments involving the application of herbicides in relation to the control was higher (65 and $47 \%$ for glyphosate and glufosinate, respectively). This could be related to the root exudation of nitrogen in the form of $\mathrm{NH}_{4}^{+}$, as a response to an increase of $\mathrm{NH}_{4}$-N levels in the plant, or even due to the death of roots caused by the action of the herbicides.

The recovery of ${ }^{15} \mathrm{~N}$-ammonium sulfate from the soil-plant system was $66.6 \%$ in the control (Table 3 ), the highest value observed among the treatments. This result is near to the value obtained by Oliveira (2001) with forage of the genus Brachiaria (59.6 to $65.3 \%)$. Based on reports available in the literature, Wetselaar \& Farquhar (1980) estimated total N losses by the aerial part in wheat, rice, grain sorghum, cotton, and rye crops to be in the order of 16 to 40,48 , 48, 21, and $42 \mathrm{~kg} \mathrm{ha}^{-1} \mathrm{~N}$, respectively. For barley, Schjoerring et al. (1993) found $\mathrm{N}-\mathrm{NH}_{3}$ losses of $1-2 \mathrm{~kg}$ $\mathrm{ha}^{-1}$ year $^{-1}$ at three nitrogen fertilization levels. For corn, Francis et al. (1993) found $\mathrm{N}$ losses of 45 to $81 \mathrm{~kg} \mathrm{ha}^{-1}$, with application rates ranging between 50 and $300 \mathrm{~kg}$ $\mathrm{ha}^{-1}$ N. For sugarcane, Kwong \& Deville (1994a,b) and Trivelin et al. (1994) estimated losses in the order of $50 \mathrm{~kg} \mathrm{ha}^{-1} \mathrm{~N}$, in studies developed independently in the Mauritius Island and Brazil, respectively.

$\mathrm{N}$ losses may probably have occurred in the above-ground part before cutting the plants in the control treatment (onset of flowering). The reason for this is that near the reproductive stages (post anthesis - beginning of senescence) there is an increase in protein hydrolysis which is accompanied by a reduction in the

Table 3 - Recovery of ammonium sulfate-N $\left({ }^{15} \mathrm{~N}\right)$ applied to the soil-plant system.

\begin{tabular}{|c|c|c|c|c|c|}
\hline Treatments & Roots & Above-ground parts* & Entire plant & Soil & Soil-plant system \\
\hline \multicolumn{6}{|c|}{ - } \\
\hline Control & 163.7 a & 312.0 a & 475.7 a & $56.2 \mathrm{~b}$ & 531.9 a \\
\hline Glyphosate & $79.0 \mathrm{~b}$ & $220.2 \mathrm{~b}$ & $299.2 \mathrm{~b}$ & 92.6 a & $391.8 \mathrm{~b}$ \\
\hline Glufosinate & $66.3 \mathrm{~b}$ & $218.1 \mathrm{~b}$ & $284.4 \mathrm{~b}$ & 82.9 a & $367.3 \mathrm{~b}$ \\
\hline CV (\%) & 32 & 27 & 25 & 19 & 21 \\
\hline \multicolumn{6}{|c|}{ - } \\
\hline Control & 20.5 a & 39.0 a & 59.5 а & $7.0 \mathrm{~b}$ & 66.5 a \\
\hline Glyphosate & $9.9 \mathrm{~b}$ & $27.5 \mathrm{~b}$ & $37.4 \mathrm{~b}$ & 11.6 a & $49.0 \mathrm{~b}$ \\
\hline Glufosinate & $8.3 \mathrm{~b}$ & $27.3 \mathrm{~b}$ & $35.5 \mathrm{~b}$ & 10.4 a & $45.9 \mathrm{~b}$ \\
\hline CV (\%) & 32 & 27 & 25 & 19 & 21 \\
\hline
\end{tabular}

Means followed by different letters, in columns, differ from each other by Tukey's Test $(p=0.05)$. *Means followed by different letters, in columns, differ from each other by Tukey's Test $(p=0.1)$ 
activities of the enzymes glutamine synthetase (GS) and glutamine:2-oxoglutarateaminotransferase (GOGAT), the main compounds responsible for ammonia assimilation in the nitrogen metabolism of higher plants, resulting in an increase of the ammonia emission potential (Morgan \& Parton, 1989). Using ${ }^{15} \mathrm{~N}$ as a tracer, Harper et al. (1987) demonstrated that after wheat anthesis, one half of the nitrogen in the grain came from a remobilization of $\mathrm{N}$ stored in stems and leaves during the breakdown process of proteins and amino acids during the maturation period of leaves and stems, while the other half came from the soil.

Ammonium toxicity occurs in plant tissues when accumulation of this ion takes place more rapidly than it is metabolized (Silva \& Stutte, 1981). The conversion into amides and amino acids and the reoxidation of $\mathrm{N}$ forms are considered $\mathrm{NH}_{3}-\mathrm{N}$ detoxification mechanisms.

Nitrogen losses in the soil-plant system were 26 and 31\% greater in the glyphosate and glufosinate treatments, respectively, relative to the control (Table 3). This result demonstrates that nitrogen losses occurred when herbicides were used. Other forms of losses of this nutrient in the experimental plots, such as soil ammonia volatilization and leaching can be discarded, because the application of ammonium sulfate was made as a solution; the pots did not have a drainage system and irrigations were performed regularly to maintain the water content at $60 \%$ of the maximum water retention capacity; no drenching occurred in the pots after the herbicides were applied; and finally, the period between the harvest of the control and the harvest of pots containing herbicide application treatments was only ten days. On the other hand, the nitrogen losses from soil as $\mathrm{N}_{2}$ and $\mathrm{N}_{2} \mathrm{O}$ could possibly occur in anaerobic microsites after herbicide application, under dryland conditions (Carmo et al., 2005). However, nitrogen losses by denitrification were small (Carmo et al., 2005), not being of importance to explain the losses that occurred in this work.

The results found in this study agree with those observed by Manderscheid et al. (2005), who verified $\mathrm{N}$ losses by the above-ground part of four weed species (Chenopodium album, Echinocloa crusgalli, Solanum nigrum, and Tripleurospermum inodorum) after application of the herbicide glufosinate-ammonium; those losses were variable among the species. C3 plants showed a reduction in total $\mathrm{N}$ contents, and lost as much as $0.4 \mathrm{~g} \mathrm{~m}^{-2} \mathrm{~N}$, while C4 plants (Echinocloa crus-galli) did not present a decrease in total $\mathrm{N}$, which may be attributed to a smaller sensitivity and smaller photorespiration rate of this species. Manderscheid et al. (2005) also evaluated the $\mathrm{NH}_{4}{ }^{+}$fraction in the total plant $\mathrm{N}$ with time (days after application of the herbicide) and observed that the $\mathrm{NH}_{4}^{+}$concentration increased by $11-13 \%$ (on average) just one day after application. The maximum fraction was observed at the end of the experiment (13 days after glufosinate application), with values ranging between 17.4 and $44 \%$ of total $\mathrm{N}$ in the plant. As previously discussed, the increase in ammonium concentration may result in higher ammonia emissions by the above-ground part of plants.

Barley plants treated with glutamine synthetase inhibitors showed greater nitrogen losses by the above-ground part after the inhibitors were applied (Mattson \& Schjoerring, 1996). Similar results were obtained by Mattson et al. (1997) during an evaluation of nitrogen losses by this route in genetically modified barley plants, with partial inhibition of glutamine synthetase.

Information on the influence of herbicides on $\mathrm{N}$ losses via this pathway is particularly important in crop-livestock farming integration systems and under the direct sowing system, where a large amount of herbicides is used for cover crop desiccation. In these systems, part of nitrogen fertilization can be made when the crop is pre-sown, by fertilizing the forage crop or, in the case of no-till, the cover plants. This practice is adopted in order to immobilize the applied fertilizer, reducing losses by leaching and favoring the gradual supply of nitrogen to the main crop. In a field study that compared forms of $\mathrm{N}$ application in a crop-livestock farming management system, Campos (2004) verified that fertilization at corn pre-seeding on brachiaria, three months before seeding, provided a $40 \%$ recovery of ${ }^{15} \mathrm{~N}$-ammonium sulfate by corn, while the application of the same $\mathrm{N}$ rate $\left(120 \mathrm{~kg} \mathrm{ha}^{-1}\right)$ as corn sidedressing resulted in $80 \%$ recovery. The recovery result obtained for pre-seeding can be attributed, in part, to $\mathrm{N}$ losses via the above-ground part, since two chemical desiccations were made on the brachiaria before planting the corn.

Therefore, the nitrogen fertilization of brachiaria or other cover crop in the direct sowing system (fertilization at pre-seeding), targeted at supplying $\mathrm{N}$ for the subsequent crop, may not be the best management strategy for nitrogen fertilizers in agricultural systems in which chemical desiccation with herbicides is adopted, since nitrogen losses by the fertilizer were significant, resulting in smaller $\mathrm{N}$ recovery in the soil-plant system. These results point toward the need for future and more detailed investigations on the causes of such $\mathrm{N}$ losses by the above-ground part of the plants, in order to prepare management strategies that will provide greater efficiency in nitrogen fertilization, so as to reduce production costs and environmental impacts caused by nitrogen fertilization. 


\section{REFERENCES}

ASMAN, W.A.H.; SUTTON, M.A.; SCHJORRING, J.K. Ammonia: emission, atmospheric transport and deposition. New Phytologist, v.139, p.27-48, 1998.

BARRIE, A.; PROSSER, S.J. Automated analysis of light-element stable isotopes by isotope ratio mass spectrometry. In: BOUTTON, T.W.; YAMSAHI, S. (Ed.) Mass spectrometry of soils. New York: Marcel Dekker, 1996. p.1-46.

CAMPOS, A.X. Fertilização com sulfato de amônio na cultura do milho em um solo do cerrado de Brasília sob pastagem de Brachiaria decumbens. Piracicaba: USP/ESALQ, 2004. 119p. Tese (Doutorado).

CARMO, J.B.; ANDRADE, C.A.; CERRI, C.C.; PICCOLO, M.C. Disponibilidade de nitrogênio e fluxos de $\mathrm{N}_{2} \mathrm{O}$ a partir de solo sob pastagem após a aplicação de herbicida. Revista Brasileira de Ciência do Solo, v.29, p.735-746, 2005.

FARQUHAR, G.D; FIRTH, P.M.; WETSELAAR, R.; WEIR, B. On the gaseous exchange of ammonia between leaves and the environment: determination of the ammonia compensation point. Plant Physiology, v.66, p.710-714, 1980.

FRANCIS, D.D.; SCHEPERS, J.S.; VIGIL, M.F. Pos-anthesis nitrogen loss from corn. Agronomy Journal, v.85, p.659-663, 1993.

HARPER, L.A.; SHARPE, R.R.; LANGDALE, G.W.; GIDDENS, J.E. Nitrogen cycling in a wheat crop: soil, plant and aerial nitrogen transport. Agronomy Journal, v.79, p.965-973, 1987.

HOAGLAND, R.E. Biochemically induced interactions of glyphosate. In: ACS NATIONAL MEETING, 18., Georgia, 1981. Abstracts. Washington, DC: American Chemical Society, 1981

HOLTAN-HARTWIG, L.; BOCKMAN, O.C. Ammonia exchange between crops and air. Norwegian Journal of Agricultural Sciences, n.14, p.52-61, 1994.

HUSTED, S.; SCHJOERRING, J.K. Ammonia Flux between oilseed rape plants and the atmosphere in response to changes in leaf temperature, light intensity, and air humidity: interactions with leaf conductance and apoplastic $\mathrm{NH}_{4}^{+}$and $\mathrm{H}^{+}$concentrations. Plant Physiology, v.112, p.67-74, 1996.

KISSMANN, K.G. Resistência de plantas daninhas a herbicidas. Available at: http://www.hrac-br/arquivos/textos_resistencia_ herbicidas.doc. Accessed 01 May 2003.

KWONG, K.F.N.K.; DEVILLE, J. Application of ${ }^{15} \mathrm{~N}$-labelled urea to sugar cane through a drip-irrigation system in Mauritius. Fertilizer Research, v.39, p.223-228, 1994a.

KWONG, K.F.N.K.; DEVILLE, J. The course of fertilizer nitrogen uptake by rain fed sugarcane in Mauritius. Journal of Agricultural Sciences, v.122, p.385-391, 1994b.

LEA, P. J. The inhibition of ammonia assimilation: a mechanism of herbicide action. In: BAKER, N.R.; PERCIVAL, M.P. (Ed.) Herbicides. Amsterdam: Elsevier Science, 1991. p.267-298.

MANDERSCHEID, R.; SCHAAF, S.; MATTSSON, M.; SCHJOERRING, J.K. Glufosinate treatment of weeds results in ammonia emission by plants. Agriculture, Ecosystems \& Environment, v.109, p.129-140, 2005.
MATTSSON, M.; SCHJOERRING, J.K. Ammonia emission from young barley plants: influence of $\mathrm{N}$ source, light/dark cycles and inhibition of glutamine synthetase. Journal of Experimental Botany, v.297, p.477-484, 1996.

MATTSSON, M.; HAUSLER, R.E.; LEEGOOD, R.C.; LEA, P.J.; SCHJOERRING, J. K. Leaf-atmosfere $\mathrm{NH}_{3}$ exchange in barley mutants with reduced activities of glutamine shynthetase. Plant Physiology, v.114, p.1307-1312, 1997.

MORGAN, J.A.; PARTON, W. J. Characteristics of ammonia volatilization from spring wheat. Crop Science, v.29, p.726731, 1989.

OLIVEIRA, P.P.A. Manejo da calagem e da fertilização nitrogenada na recuperação de pastagens degradadas de Brachiaria sp. em solos arenosos. Piracicaba: USP/CENA 2001. 110p. Tese (Doutorado).

PARTON, W.J.; MORGAN, J.A.; ALTENHOFEN, J.M.; HARPER, L.A. Ammonia volatilization from spring wheat plants. Agronomy Journal, v.80, p.419-425, 1988.

PENATTI, C.P.; FORTI, J.A. Calcário e gesso em cana-de-açúcar. In: SEMINÁRIO DE TECNOLOGIA AGRONÔMICA, 6., Piracicaba, 1994. Anais. Piracicaba: Centro de Tecnologia Copersucar, 1994. p.83-98.

SHERLOCK, R.R.; FRENEY, J.R.; SMITH, N.P.; CAMERON, K.C. Evaluation of a sampler for assessing ammonia losses from fertilized fields. Fertilizer Research, v.21, p.61-66, 1989

SCHJOERRING, J.K.; KYLLINGSBAEK, A.; MORTNSEN, J.V.; BYSKOVI-NIELSEN, S. Field investigations of ammonia exchange between barley plants and the atmosphere. I. Concentration profiles and flux densities of ammonia. Plant Cell and Environment, v.16, p.161-167, 1993.

SCHJOERRING, J.K.; HUSTED, S.; MATTSON, M. Physiological parameters controlling plant-atmosferic ammonia exchange. Atmosferic Environmental, v.32, p.491-498, 1998.

SILVA, P.R.F.; STUTTE, C.A. Nitrogen volatilization from rice leaves. II. Effects of source of applied nitrogen in nutrient culture solution. Crop Science, v.21, p.913-916, 1981.

SUTTON, M.A.; PITCAIRN, C.E.R.; FOWLER, D. The exchange of ammonia between the atmosphere and plant communities. Advances in Ecology Research, v.24, p.301-393, 1993.

TRIVELIN, P.C.O.; LARA CABEZAS, W.A.R.; VICTORIA, R.L.; REICHARDT, K. Evaluation of a ${ }^{15} \mathrm{~N}$ plot design for estimating plant recovery of fertilizer nitrogen applied to sugar cane. Scientia Agricola, v.51, p.226-234, 1994.

WETSELAAR, R.; FARQUHAR, G.D. Nitrogen losses from tops of plants. Advances in Agronomy, v.33, p.263-302, 1980.

WILD, A.; MANDERSCHEID, R. The effect of phosphinothricin on the assimilation of ammonia in plants. Zeitschrift fur Naturforschung, v.39, p.500-504, 1984.

Received October 31, 2006

Accepted November 29, 2007 